\title{
THE CHANGE OF SOME HEAVY METAL CONCENTRATIONS IN SCOTCH PINE (PINUS SYLVESTRIS) DEPENDING ON TRAFFIC DENSITY, ORGANELLE AND WASHING
}

\author{
ARICAK, B. ${ }^{1}-$ CETIN, M. ${ }^{2 *}-$ ERdEM, R. ${ }^{3}-$ SEVIK, H. $^{4}-$ COMETEN, H. $^{5}$ \\ ${ }^{I}$ Department of Forest Engineering, Faculty of Forestry, Kastamonu University, \\ Kastamonu, Turkey \\ (phone: +90-366-280-1744; fax: +90-366-215-2316) \\ ${ }^{2}$ Department of Landscape Architecture, Faculty of Engineering and Architecture, Kastamonu \\ University, Kastamonu, Turkey \\ ${ }^{3}$ Department of Forestry, Arac Rafet Vergili Vocational School, Kastamonu University, \\ Kastamonu, Turkey \\ (phone: +90-366-280-1744; fax: +90-366-215-2316) \\ ${ }^{4}$ Department of Environmental Engineering, Faculty of Engineering and Architecture, \\ Kastamonu University, Kastamonu, Turkey \\ (phone: +90-366-280-2921; fax: +90-366-280-2900) \\ ${ }^{5}$ Programs of Forest Engineering, Institute of Science, Kastamonu University, \\ Kastamonu, Turkey \\ (phone: +90-366-280-1744; fax: +90-366-215-2316) \\ *Corresponding author \\ e-mail: mcetin@kastamonu.edu.tr; phone:+90-366-280-2920; fax:+90-366-280-2900 \\ (Received $6^{\text {th }}$ Feb 2019; accepted $8^{\text {th }}$ Apr 2019)
}

\begin{abstract}
Increasing population and industrialization have caused air pollution and air pollution in some cities has increased to such an extent that it has started to threaten human health and has become one of the most important agenda topics of our day. Many pollutants arise in cities due to exhaust gases, car wheels, vehicles and vehicle wear. Heavy metals are one of the most infamous pollutants, because they can remain in nature for a long time without degradation and the amount of heavy metal concentration in the environment is constantly increasing. Heavy metals also tend to bioaccumulate. Therefore, the determination of heavy metal concentration is of great importance in terms of identifying risk regions and risk levels. Determination of heavy metal concentrations in plants is important both for determining plants' ability to remove heavy metals from the air and thus to improve air quality, as well as for monitoring air quality. Bio-indicators are the most important indicators of the change in the concentration of heavy metal in the atmosphere. This study aims to determine the usability potential of Scotch Pine (Pinus sylvestris) in monitoring the traffic related heavy metal concentration. For this purpose, samples of Scotch Pine individuals were collected from one of the busiest highways of Turkey, at the route of Ankara-Istanbul, from refuges, at roadsides and at distances of $3 \mathrm{~m}, 10 \mathrm{~m}, 30 \mathrm{~m}, 50 \mathrm{~m}$ and $100 \mathrm{~m}$ from the roadside, some of the branch and needle samples were washed and the change of $\mathrm{Cu}, \mathrm{Pb}$ and $\mathrm{Cd}$ concentrations on these samples was determined. As a result of the study, the change of the concentrations of these heavy metals depending on distance to the road, organelle and washing conditions all seem to indicate that the Scotch Pine is a good bio-monitor which could be used especially to monitor the change of Cd concentration.
\end{abstract}

Keywords: bioaccumulate, bio-monitor, highway, plant, pollution, Cd concentration 


\section{Introduction}

In addition to the rising population of the world, the increasing population density in city centers has brought various problems with it (Cetin and Sevik, 2016a, b; Gülgün et al., 2014; Cetin et al., 2017a, b, 2018a, b, c, d). This process causes destruction of nature, pollution of air, water and soil, and deterioration of the ecological balance (Mutlu, 2016; Mutlu et al., 2016; Kaya et al., 2018). This process brings many problems with it, but one of the biggest problems is the pollution of environment and especially air (Sevik et al., 2018). Air pollution has become such a big problem that approximately 30 million people die every year due to air pollution related reasons (Cetin et al., 2018).

Air pollution can be defined as the existence of one or more contaminants in the air in amounts and durations which could be harmful to humans, animals and plant life and commercial or personal properties and environmental quality (Cetin et al., 2018).

While there are many components responsible for air pollution, heavy metals are one of the more significant among them. Heavy metals do not deteriorate and disappear in nature.

There are various methods that are used to determine the air pollution. Direct measurement of air pollution via these methods requires both expensive measuring instruments and has a higher risk of contamination compared to bioindicators. Plants have many environmental, social and economic contributions to the environment in which we live, one of which is their use as a bio-indicator in the detection and monitoring of air pollution (Gülgün et al., 2015; Cetin et al., 2018b). Using bioindicators is one of the most effective methods of determining air pollution.

This method is inexpensive and easy to provide, as well as its ability to provide more accurate data on the periodic change of heavy metal concentration. Therefore, many studies have been conducted to determine the change of heavy metal concentrations via bioindicators (Sevik et al., 2018; Turkyilmaz et al., 2018b).

However, different heavy metals can accumulate at different levels in the organelles of the plants. Therefore, it is very important to determine the accumulation level of each heavy metal in each organnelle to enable the usage of the right organelle of the right plant as biomonitors in order to get more reliable results from the studies. In this study, it was aimed to determine the change of some heavy metals concentrations depending on the plant organelles and the distance to the road with heavy traffic in Scotch Pines (Pinus sylvestris).

\section{Materials and methods}

\section{Materials}

The study was conducted on the samples collected from the Scotch Pines from the roadside on the Ankara-İstanbul highway between Kaynaşlı province of Düzce city and Bolu city. The highway that was chosen as the case of this study is one of the busiest highways in Turkey. Samples were especially taken from the closest branches to the road. The Scotch Pine individuals were selected on a specific direction on the highway between Kaynaşlı district of Düzce province and Bolu province from the refuge, roadside and at $3 \mathrm{~m}, 10 \mathrm{~m}, 30 \mathrm{~m}, 50 \mathrm{~m}$ and $100 \mathrm{~m}$ distances. The half-meter length of branch samples collected from the road side parts of seven Scotch Pines constitute the materials of this study (Table 1). The samples used in the study were collected in the last week of September following the end of the vegetation season of 2018. 
Table 1. The exact locations of sampling indicated by GPS coordinates

\begin{tabular}{c|c|c}
\hline \multirow{2}{*}{ Distance (m) } & \multicolumn{2}{|c}{$\begin{array}{c}\text { Coordinates DMS } \\
\text { (degrees, minutes, seconds) }\end{array}$} \\
\cline { 2 - 3 } & Latitude N & Longitude E \\
\hline 0 & $40^{\circ} 46^{\prime} 32.225^{\prime \prime}$ & $31^{\circ} 19^{\prime} 41.524^{\prime \prime}$ \\
1 & $40^{\circ} 46^{\prime} 45.450^{\prime \prime}$ & $31^{\circ} 19^{\prime} 25.086^{\prime \prime}$ \\
3 & $40^{\circ} 46^{\prime} 48.105^{\prime \prime}$ & $31^{\circ} 19^{\prime} 53.024^{\prime \prime}$ \\
10 & $40^{\circ} 47^{\prime} 09.660^{\prime \prime}$ & $31^{\circ} 18^{\prime} 22.076^{\prime \prime}$ \\
30 & $40^{\circ} 47^{\prime} 36.155^{\prime \prime}$ & $31^{\circ} 18^{\prime} 39.323^{\prime \prime}$ \\
50 & $40^{\circ} 48^{\prime} 07.464^{\prime \prime}$ & $31^{\circ} 17^{\prime} 23.096^{\prime \prime}$ \\
100 & $40^{\circ} 48^{\prime} 23.124^{\prime \prime}$ & $31^{\circ} 17^{\prime} 15.233^{\prime \prime}$ \\
\hline
\end{tabular}

\section{Determination of heavy metal concentrations}

Samples brought to the laboratory were firstly divided into groups and some of the samples were washed. The samples were then separated into organelles and the bark of the wood was peeled; and washed needles, unwashed needles, washed bark, unwashed bark and wood samples were obtained. The samples were labeled and kept for 15 days until they got air dried. Air dried samples were taken into glass containers and dried in drying oven at $50{ }^{\circ} \mathrm{C}$ for one week.

The dried samples were pulverized by a steel blender in the laboratory. The pulverized samples were made to weigh $2 \mathrm{~g}$ each in $10 \mathrm{ml}$ concentrated $\mathrm{HNO}_{3}$ at room temperature for 1 day in the fume cupboard, and then boiled at $180{ }^{\circ} \mathrm{C}$ for $1 \mathrm{~h} .20 \mathrm{ml}$ of distilled water were added to the prepared solutions and the solution was filtered through a $45-\mu \mathrm{m}$ filter paper. The prepared solutions were numbered in order to prevent any mix-ups and prepared for analysis. In the solutions obtained from the filtrate; heavy metal analysis was performed with the GBC Integra XL ICSDS-270 ICP-OES (Inductively Coupled Plasma Optical Emission Spectrometer) device (Sevik et al., 2018; Turkyilmaz et al., 2018b).

\section{Statistical analysis}

The obtained data were evaluated with the help of SPSS package program, variance analysis was applied to the data and homogeneous groups were obtained by applying the Duncan test to the values having at least 95\% confidence level differences statistically. The obtained data is simplified and tabulated and interpreted (Sevik et al., 2018; Turkyilmaz et al., 2018b).

\section{Results}

The change in $\mathrm{Cu}$ concentration due to organelle and distance to the traffic source was determined separately and F value and significance level obtained by variance analysis and homogeneous groups resulting from Duncan test are shown in Table 2.

As the result of the variance analysis, it was determined that the change of $\mathrm{Cu}$ concentration was significant at a $99.9 \%$ confidence level for all factors. When the change of $\mathrm{Cu}$ concentration due to distance was examined, no significant change was observed. For example, in the unwashed bark samples, some of the lowest and the 
highest values were obtained at the farthest distance from the road. A similar situation is also noticeable in wood samples. The lowest and the highest values of the wood samples were also obtained at the farthest distance to the road.

Table 2. The change of $\mathrm{Cu}(\mathrm{ppm})$ concentration depending on organelle and on distance from the road

\begin{tabular}{c|c|c|c|c|c|c}
\hline \multirow{2}{*}{$\begin{array}{c}\text { Distance } \\
(\mathbf{m})\end{array}$} & \multicolumn{2}{|c|}{ Needle } & \multicolumn{2}{c|}{ Bark } & \multirow{2}{*}{ Wood (ppm) } & Value (ppm) \\
\cline { 2 - 5 } & $\begin{array}{c}\text { Washed } \\
(\mathbf{p p m})\end{array}$ & $\begin{array}{c}\text { Unwashed } \\
(\mathbf{p p m})\end{array}$ & $\begin{array}{c}\text { Washed } \\
(\mathbf{p p m})\end{array}$ & $\begin{array}{c}\text { Unwashed } \\
(\mathbf{p p m})\end{array}$ & & \\
\hline 0 & $1642.8 \mathrm{Ce}$ & $783.7 \mathrm{Ac}$ & $1274.6 \mathrm{Bc}$ & $6094.9 \mathrm{Df}$ & $6461.1 \mathrm{Eg}$ & $3615.463^{* * *}$ \\
1 & $786.5 \mathrm{Bb}$ & $220.4 \mathrm{Aa}$ & $2956.5 \mathrm{De}$ & $1620.2 \mathrm{Cc}$ & $128.7 \mathrm{Aa}$ & $897.041^{* * *}$ \\
3 & $1034.6 \mathrm{Bc}$ & $559.3 \mathrm{Ab}$ & $1295.5 \mathrm{Cc}$ & $1020.1 \mathrm{Bb}$ & $2728.2 \mathrm{Dd}$ & $294.611^{* * *}$ \\
10 & $1909.5 \mathrm{Cg}$ & $1124.9 \mathrm{Ad}$ & $1686.0 \mathrm{Bd}$ & $1880.3 \mathrm{Cd}$ & $3170.6 \mathrm{De}$ & $193.553^{* * *}$ \\
30 & $1787.9 \mathrm{Df}$ & $1572.0 \mathrm{Ce}$ & $503.1 \mathrm{ABa}$ & $332.0 \mathrm{Aa}$ & $561.2 \mathrm{Bb}$ & $127.001^{* * *}$ \\
50 & $1418.0 \mathrm{Dd}$ & $1482.4 \mathrm{De}$ & $712.5 \mathrm{Bb}$ & $194.3 \mathrm{Aa}$ & $834.8 \mathrm{Cc}$ & $203.899^{* * *}$ \\
100 & $550.2 \mathrm{Aa}$ & $1805.6 \mathrm{Cf}$ & $1321.8 \mathrm{Bc}$ & $2759.7 \mathrm{De}$ & $5296.4 \mathrm{Ef}$ & $1390.201^{* * *}$ \\
& $237.794 * * *$ & $174.617^{* * *}$ & $209.164^{* * *}$ & $1024.679^{* * *}$ & $3880.312^{* * *}$ & \\
\hline
\end{tabular}

*Significant at 0.05 level; **significant at 0.01 level; ***significant at 0.001 level

The letters a, b, c, etc. means according to Duncan test results; show that the group is located. It is statistically different from the values contained in different groups, starting with the letter a, the numerical value grows

Capital letters in rows; lower case letters show groupings in columns. For example, the concentration of $\mathrm{Cu}$ in the washed needle is also as the distance of the fifth; $\mathrm{C}$ is in the third homogeneous group

When examining the change of $\mathrm{Cu}$ concentration depending on the organelles; it is noteworthy that the concentration amounts in wood samples were considerably high. It was observed that the amount of the $\mathrm{Cu}$ concentration in wood samples were higher than the values obtained from the other organelles.

The change in $\mathrm{Pb}$ concentration due to organelle and distance to the traffic source was determined separately and F value and significance level obtained by variance analysis and homogeneous groups resulting from Duncan test are shown in Table 3.

When the results of the analysis of variance in $\mathrm{Pb}$ are examined, it is noteworthy that $\mathrm{Pb}$ concentration in wood does not differ statistically significant at least at $95 \%$ confidence level depending on distance. Apart from this, it can be said that the change of $\mathrm{Pb}$ concentration due to distance is statistically meaningless. However, when the change of $\mathrm{Pb}$ concentration is examined depending on organelle, it is observed that all values obtained from the wood samples are quite low and all the values obtained from the wood samples are in the first two homogenous groups that were formed as the result of Duncan test. Furthermore, it was observed that the values obtained from needles were lower than the values obtained from the bark samples, while the values of washed samples were also lower than the values of unwashed samples.

The change in $\mathrm{Cd}$ concentration due to organelle and distance to the traffic source was determined separately and $\mathrm{F}$ value and significance level obtained by variance analysis and homogeneous groups resulting from Duncan test are shown in Table 4.

As the result of the variance analysis, it was determined that the change of $\mathrm{Cd}$ concentration was significant at a $99.9 \%$ confidence level for all factors. When the 
change of $\mathrm{Cd}$ concentration due to distance was examined, it was seen that $\mathrm{Cd}$ concentration decreases generally as the distance increases.

Table 3. The change of $\mathrm{Pb}$ (ppm) concentration depending on organelle and distance

\begin{tabular}{|c|c|c|c|c|c|c|}
\hline \multirow{2}{*}{$\begin{array}{c}\text { Distance } \\
\text { (m) }\end{array}$} & \multicolumn{2}{|c|}{ Needle } & \multicolumn{2}{|c|}{ Bark } & \multirow{2}{*}{$\begin{array}{c}\text { Wood } \\
\begin{array}{c}\text { Unwashed } \\
(p p m)\end{array}\end{array}$} & \multirow[b]{2}{*}{ Value (ppm) } \\
\hline & $\begin{array}{c}\text { Washed } \\
\text { (ppm) }\end{array}$ & $\begin{array}{c}\text { Unwashed } \\
\text { (ppm) }\end{array}$ & $\begin{array}{c}\text { Washed } \\
\text { (ppm) }\end{array}$ & $\begin{array}{c}\text { Unwashed } \\
\text { (ppm) }\end{array}$ & & \\
\hline 0 & $267.9 \mathrm{Abc}$ & $337.1 \mathrm{Ab}$ & 1246.2 Bb & 1304.1 Bbc & $361.6 \mathrm{~A}$ & $41.008 * * *$ \\
\hline 1 & $93.6 \mathrm{Aa}$ & $765.6 \mathrm{Ccd}$ & 1592.2 Dc & 1766.1 Dd & $421.7 \mathrm{~B}$ & $122.962 * * *$ \\
\hline 3 & $371.4 \mathrm{Ac}$ & $1042.4 \mathrm{Be}$ & $1110.1 \mathrm{Bb}$ & $1023.0 \mathrm{Ba}$ & $273.1 \mathrm{~A}$ & $22.517 * * *$ \\
\hline 10 & $258.2 \mathrm{Abc}$ & $458.5 \mathrm{Ab}$ & $2131.8 \mathrm{Dd}$ & $1778.7 \mathrm{Cd}$ & $404.7 \mathrm{~A}$ & $82.814 * * *$ \\
\hline 30 & 150.1 Aab & $74.3 \mathrm{Aa}$ & $947.6 \mathrm{Cb}$ & $1070.8 \mathrm{Cab}$ & $581.6 \mathrm{~B}$ & $39.022 * * *$ \\
\hline 50 & $321.2 \mathrm{Ac}$ & $656.2 \mathrm{Bc}$ & $1089.1 \mathrm{Cb}$ & 1196.7 Cab & $371.2 \mathrm{~A}$ & $33.357 * * *$ \\
\hline \multirow[t]{2}{*}{100} & 219.4 Aabc & $942.3 \mathrm{Cde}$ & $395.2 \mathrm{Aa}$ & 1455.2 Dc & $581.2 \mathrm{~B}$ & $70.513 * * *$ \\
\hline & $3.936^{*}$ & $31.334 * * *$ & $27.357 * * *$ & $15.223 * * *$ & $2.096 \mathrm{~ns}$ & \\
\hline
\end{tabular}

*Significant at 0.05 level; **significant at 0.01 level; ***significant at 0.001 level

The letters a, b, c, etc. means according to Duncan test results; show that the group is located. It is statistically different from the values contained in different groups, starting with the letter a, the numerical value grows

Capital letters in rows; lower case letters show groupings in columns. For example, the concentration of $\mathrm{Cu}$ in the washed needle is also as the distance of the fifth; $\mathrm{C}$ is in the third homogeneous group

Table 4. The change of $C d(p p m)$ concentration depending on organelle and distance

\begin{tabular}{c|c|c|c|c|c|c}
\hline \multirow{2}{*}{$\begin{array}{c}\text { Distance } \\
(\mathbf{m})\end{array}$} & \multicolumn{2}{|c|}{ Needle } & \multicolumn{2}{c|}{ Bark } & Wood & \multirow{2}{*}{ Value (ppm } \\
\cline { 2 - 6 } & $\begin{array}{c}\text { Washed } \\
(\mathbf{p p m})\end{array}$ & $\begin{array}{c}\text { Unwashed } \\
(\mathbf{p p m})\end{array}$ & $\begin{array}{c}\text { Washed } \\
(\mathbf{p p m})\end{array}$ & $\begin{array}{c}\text { Unwashed } \\
(\mathbf{p p m})\end{array}$ & $\begin{array}{c}\text { Unwashed } \\
(\mathbf{p p m})\end{array}$ & \\
\hline 0 & $40.8 \mathrm{Ac}$ & $65.9 \mathrm{Ac}$ & $172.4 \mathrm{Ce}$ & $157.0 \mathrm{BCc}$ & $138.8 \mathrm{Bb}$ & $36.731 * * *$ \\
1 & $14.7 \mathrm{Aa}$ & $32.8 \mathrm{Bab}$ & $81.5 \mathrm{Cc}$ & $69.9 \mathrm{Ca}$ & $45.4 \mathrm{Ba}$ & $35.040^{* * *}$ \\
3 & $25.9 \mathrm{Ab}$ & $41.1 \mathrm{Bb}$ & $80.6 \mathrm{Dc}$ & $53.9 \mathrm{Ca}$ & $43.2 \mathrm{Ba}$ & $95.119^{* * *}$ \\
10 & $17.3 \mathrm{Aa}$ & $25.0 \mathrm{Aa}$ & $114.0 \mathrm{Cd}$ & $95.0 \mathrm{Cb}$ & $46.0 \mathrm{Ba}$ & $45.881^{* * *}$ \\
30 & $19.0 \mathrm{Aa}$ & $25.2 \mathrm{Aa}$ & $73.6 \mathrm{Dbc}$ & $50.9 \mathrm{Ca}$ & $39.9 \mathrm{Ba}$ & $31.902 * * *$ \\
50 & $26.6 \mathrm{Ab}$ & $26.0 \mathrm{Aa}$ & $61.4 \mathrm{Cab}$ & $57.5 \mathrm{Ca}$ & $40.4 \mathrm{Ba}$ & $103.357 * * *$ \\
100 & $19.3 \mathrm{Aa}$ & $36.4 \mathrm{Bab}$ & $46.9 \mathrm{Ca}$ & $65.2 \mathrm{Da}$ & $39.5 \mathrm{BCa}$ & $27.582 * * *$ \\
\hline
\end{tabular}

*Significant at 0.05 level; **significant at 0.01 level; $* * *$ significant at 0.001 level

The letters a, b, c, etc. means according to Duncan test results; show that the group is located. It is statistically different from the values contained in different groups, starting with the letter a, the numerical value grows

Capital letters in rows; lower case letters show groupings in columns. For example, the concentration of $\mathrm{Cu}$ in the washed needle is also as the distance of the fifth; $\mathrm{C}$ is in the third homogeneous group

When the change of $\mathrm{Cd}$ concentration depending on the organelles was examined, it was determined that the lowest values were obtained from the needle samples, the highest values were obtained from bark samples, and the values obtained from wood samples were higher than the values of needle samples while lower than the values of bark samples. Apart from that, the Cd concentration amount calculated in unwashed 
needle samples were generally higher than the washed needle samples, and the Cd concentration amount calculated in washed bark samples were higher than the unwashed bark samples.

In addition, the $\mathrm{Cd}$ concentrations obtained from the unwashed samples in the hands are generally higher than the washed samples and the Cd concentrations in the washed samples are higher than the $\mathrm{Cd}$ concentrations obtained in the washed samples.

\section{Discussion}

Plants are often used as biomonitors in monitoring the heavy metal concentration. Some of the species that are used as biomonitors of traffic related air pollution are; Aesculus hippocastanum (Anicic et al., 2011), Elaeagnus angustifolia (Aksoy and Şahin, 1999), Robinia pseudoacacia (Celik et al., 2005), Tilia sp. (Tomasevic and Anicic, 2010), Quercus ilex (Gratani et al., 2008) and some other species (Ozturk and Bozdogan, 2015; Mossi, 2018).

$\mathrm{Cu}$, one of the heavy metals that were evaluated within the scope of this study is quite an important element for plant organisms due to its involvement in enzyme activation, carbohydrate and lipid metabolism (Asri and Sönmez, 2006). It has been determined that copper plays an important role in physiological events such as photosynthesis, respiration, carbohydrate degradation, nitrogen use and storage, cell wall metabolism, and that it regulates xylem permeability, controls the production of DNA and RNA and plays an important role in resistance mechanism against diseases. In case of copper deficiency, it is stated that plant growth stopped (Okcu et al., 2009).

Although plant species need different amounts of it, copper is a highly toxic metal. Some effects of copper poisoning include tissue damage, deterioration of roots and darkening of plant color. Other effects of copper poisoning are, loss of ion as a result of deterioration of membrane permeability in the stem cells and disruption of photosynthesis process as a result of DNA damage (Okcu et al., 2009). Acute copper intoxication may cause abdominal pain, nausea, vomiting and diarrhea in humans (Asri and Sönmez, 2006). While taking low amounts of copper ions may cause liver cirrhosis, Wilson's disease, systemic rheumatic diseases, kidney diseases; taking high amounts of copper ions may cause blood cancer (Mossi, 2018). Therefore, many studies have been conducted to determine $\mathrm{Cu}$ concentration in plants and to correlate with traffic density (Turkyilmaz et al., 2018a, b).

Turkyilmaz et al. (2018c) stated that $\mathrm{Cu}$ concentration amount in plant organelles differ depending on traffic density and that while they calculated the $\mathrm{Cu}$ concentration at $69.615 \mathrm{ppb}$ in areas with none-traffic, it was $71.096 \mathrm{ppb}$ in areas with low dense traffic and it reached up to $110.441 \mathrm{ppb}$ level in areas with heavy traffic. Suzuki et al. (2009) determined that the concentration of $\mathrm{Cu}$ could reach up to $22.22 \mathrm{mg} \mathrm{kg}^{-1}$ in the leaves of Rhododendron pulchrum in Okayama, Japan; while Demirayak et al. (2011) reported that $\mathrm{Cu}$ concentration was averagely at $35 \mathrm{ppm}$ level in the leaves of $M$. grandiflora in Samsun city. Li et al. (2007) stated that the amount of $\mathrm{Cu}$ concentration in Sophora japonica L. leaves were higher in the individual trees on roadside than the ones in the parks.

Sawidis et al. (2011) determined that the Cu concentration in Pinus nigra leaves in the control group was calculated at $3.182 \mu \mathrm{g} / \mathrm{g}$ in Salzburg; $3.263 \mu \mathrm{g} / \mathrm{g}$ in Belgrade; and $2.432 \mu \mathrm{g} / \mathrm{g}$ in Thessaloniki; while it increased up to $4.875 \mu \mathrm{g} / \mathrm{g}$ in Salzburg; $25.391 \mu \mathrm{g} / \mathrm{g}$ in Belgrade and $16.486 \mu \mathrm{g} / \mathrm{g}$ in Thessaloniki in contaminated regions. 
Erdem (2018) in his study on different species that the $\mathrm{Cu}$ concentration between 0.16 and $24.66 \mathrm{ppm}$ and depending on the intensity of the traffic varies depending on a high level of values, for example, Ailanthus altissima in the areas of heavy traffic in the $\mathrm{Cu}$ concentration of the determined concentration of $\mathrm{Cu}$ in areas where the approximately 80 times. Pinar (2019) in his study of five species on the $\mathrm{Cu}$ concentration of $3 \mathrm{ppm}$ to $286.5 \mathrm{ppm}$ ranged between the highest value of the traffic is concentrated in the linden seeds.

$\mathrm{Cu}$ concentration in wood samples was higher than in the other organelles. This result is generally consistent with the literature. $\mathrm{Cu}$ concentration varies in different species, depending on species and organelles (Mossi, 2018; Turkyilmaz et al., 2018d).

In his study of four different types, Erdem (2018) states that the $\mathrm{Cu}$ concentration changes significantly on the basis of the organelle. In some species, the highest values are determined on the leaf and in some species on the branches and seeds. Similar results were obtained by Özel (2019) and Pınar (2019). Pb is one of the other heavy metals that were evaluated within this study. $\mathrm{Pb}$ concentration is of great importance among the other heavy metals. $\mathrm{Pb}$, which is a widely used element in industrial and agricultural activities, is a heavy metal that is emitted to the atmosphere as a metal or compound and in each case has toxic properties. $\mathrm{Pb}$ is one of the heavy metals that cause the most damage to the ecological system by human activities (Mossi, 2018). Therefore, a large number of studies have been performed on the change of $\mathrm{Pb}$ due to traffic density (Lei et al., 2015; Assirey et al., 2015; Galal et al., 2015).

In the study, it was determined that the values obtained in the wood samples were quite low, and the values obtained from the needle samples were lower than the values obtained from the bark samples and the values obtained from the washed samples were lower than the values obtained from the unwashed samples. Mossi (2018) found similar results in different studies; he determined that the lowest values of $\mathrm{Pb}$ concentrations were obtained from washed samples while the highest values were calculated in the unwashed samples in areas with heavy traffic.

$\mathrm{Pb}$ with more than the normal levels can be found in the foods of animal and vegetable origin that are grown in areas close to the city centers and industrial regions (França et al., 2017; Mossi, 2018). In addition, lead-containing gasoline is an important source (Okcu et al., 2009). Therefore, there are numerous studies documenting the relationship between $\mathrm{Pb}$ and traffic density (Qing et al., 2015; Begum et al., 2017).

Erdem (2018) stated that different types of $\mathrm{Pb}$ concentrations vary significantly depending on the traffic density, whereas the average $\mathrm{Pb}$ concentration in areas where there is no traffic is $346 \mathrm{ppb}$ is $635 \mathrm{ppb}$ in areas with low traffic and $1782 \mathrm{ppb}$ in high traffic areas. Pinar (2019) stated that Pb concentration increased with traffic density and this level was quite high in some organelles.

There are many studies on the change of $\mathrm{Pb}$ in organelle and species. In studies, it is stated that $\mathrm{Pb}$ changes significantly on organelle basis. For example, Akarsu (2019) stated that the $\mathrm{Pb}$ concentration in Cedrus arizonica wood was $1619 \mathrm{ppb}$ and this value increased to $5902 \mathrm{ppb}$ in the outer shell. Ozel (2019) indicates that the concentration of $\mathrm{Pb}$ in the mulberry shells in the areas where there is no traffic is increased to $2630 \mathrm{ppb}$ in the leaves. The same figures in the areas where traffic is $5352 \mathrm{ppb}$ in the shell, $11582 \mathrm{ppb}$ level in the leaf (Ozel, 2019).

$\mathrm{Pb}$ is one of the most studied elements due to the properties of this element. Numerous studies have been conducted on many species to be used as the biomonitor of $\mathrm{Pb}$. Some of the studies that were aimed to determine the change of $\mathrm{Pb}$ concentration in 
different species depending on traffic density are; Aksoy and Şahin (1999) Elaeagnus angustifolia, Tam et al. (1987) Bauhina varigeata, Çelik et al. (2005) Robinia pseudoacacia, Demirayak et al. (2011) M. grandiflora and A. Cyanophylla, Tanushree et al. (2011) Alstonia scholaris, Ficus bengalensis, Morus alba, and Polyalthia longifolia, Sawidis et al. (2011) Platanus orientalis (Ozel et al., 2015), Pinus nigra, Li et al. (2007) Sophora japonica.

Another heavy metal that has been mostly studied is $\mathrm{Cd}$. $\mathrm{Cd}$ is a highly toxic metal that comes to the fore with a variety of usage areas and with its role in the environmental pollution. The carcinogen effect of $\mathrm{Cd}$ in human body was identified in 1976 and it was classified as Type 1 carcinogen by IARC (International Agency for Cancer Research) in 1993 (Boğa, 2007). Cd is an element that is toxic for both humans and animals as well as plants (Asri and Sönmez, 2006; Boğa, 2007). Not only is it toxic for the human body even at very low doses, but it also has a long biological half-life.

In addition to industrial activities, cadmium is spread through phosphorous fertilizers used in agriculture, sewage wastes in residential areas and atmospheric deposits. It is estimated that $0.2-1.0 \mathrm{mg} / \mathrm{m}^{2}$ of $\mathrm{Cd}$ is added annually in the soils of the roadsides in areas with heavy traffic (Asri and Sönmez, 2006). In our study, it was determined that $\mathrm{Cd}$ concentration decreased as the distance to the road increased. In addition, the lowest values were obtained in needles while the highest values were obtained in bark samples.

The results of the study revealed that the amount of $\mathrm{Cd}$ changed depending on both traffic density and organelle. In a large number of studies, it was determined that the concentration of $\mathrm{Cd}$ varies according to plant species, traffic density and plant organnelle (Mossi, et al., 2018; Turkyilmaz et al., 2018e). Ozel (2019) Cd concentration, depending on the type, organelle and traffic density, Akarsu (2019) Cedrus arizonica facing the road in the average $\mathrm{Cd}$ concentration of wood at $157 \mathrm{ppb}$ level of this value is $2601 \mathrm{ppb}$ level in the outer shell.

In this study, the possibility of using pine as a biomonitor to determine the heavy metal pollution in the air was investigated. It is stated in the studies that it can be used as biomonitor in determining the heavy metal pollution of traffic origin of pine in different areas (Turkyilmaz et al., 2018b). In order for a species to be used as a biomonitor for monitoring heavy metal pollution, it must first be able to collect heavy metals within that species (Bat et al., 1999). Plants that can collect heavy metals in the air can also remove heavy metals from the air. Therefore, they can clean the air in terms of heavy metal. Therefore, the plants that can collect heavy metals within the body can also contribute to the cleaning of the heavy metal. This situation was also expressed in other studies (Saleh, 2018; Mossi, 2018; Erdem, 2018). In this study, it was determined that pine can collect some heavy metals within its structure. Therefore, in the environment where yellow pine is grown, it will help to remove heavy metals from the air and contribute to the cleaning of air pollution.

\section{Conclusions}

Expanding green areas is one of the most effective methods among the solution proposals to tackle air pollution. In many studies, it has been proved that green areas and the plants used in these areas reduce all kinds of air pollution in different ways (Cetin and Sevik, 2016a, b; Cetin et al., 2017).

Although a large number of plant species have been the subject of studies to date, these studies are not yet sufficient. There is no information about the potential of many 
plant species to accumulate heavy metals. However, it has been reported in numerous studies that there are great differences between the heavy metal deposition potentials of plant species. Therefore, it is necessary to use the species that are not examined yet in similar studies and to identify the plants that will be more effective in monitoring and reducing the heavy metal pollution. Therefore, it is suggested to keep similar studies going by diversifying the studied plant species.

In the selection of the plants used in urban centers, their visual qualities are generally prioritized and their functional uses are made to be of secondary importance. However, in order to use the plants in a proper manner; it is vital to determine the more effective species to perform the desired function and the selection of the species in such areas should be made accordingly. Scotch pine is a tree species that can be used for forestation of the urban areas especially due to being an evergreen species as well as being extremely resistant to cold climates. Also, as it has low needs for maintenance, soil and water tree, it is a valuable landscape plant. It is determined that it is also a good biomonitor especially for the monitoring of Cd pollution.

Within the scope of the study, measurements have only been conducted on needles, branches and wood samples of the tree. However, former studies have proved that the heavy metal concentration in different organelles of the plants such as root, fruit, etc. can be higher. Therefore, the low concentration in the needles, branches and wood samples of a tree may not mean that the plant does not accumulate heavy metals as the plant may have a significant amount of heavy metal concentration in its other organelles. The inclusion of other organelles of the plants in the studies to be carried out in this field may provide important results.

\section{REFERENCES}

[1] Aksoy, A., Sahin, U. (1999): Elaeagnus angustifolia L. as a biomonitor of heavy metal pollution. - Turkish Journal of Botany 23: 83-87.

[2] Akarsu, H. (2019): Determination of heavy metal accumulation in atmosphere by being aid of annual rings. - Master Thesis, Kastamonu University, Graduate School of Natural and Applied Sciences Department of Sustainable Agriculture and Natural Plant Resources, Kastamonu, Turkey.

[3] Anicic, M., Spasic, T., Tomasevic, M., Rajsic, S., and Tasic, M. (2011): Trace elements accumulation and temporal trends in leaves of urban deciduous trees (Aesculus hippocastanum and Tilia ssp.). - Ecological Indicators 11: 824-830.

[4] Asri, F. Ö., Sönmez, S. (2006): Ağır metal toksisitesinin bitki metabolizması üzerine etkileri. - Derim, Batı Akdeniz Tarımsal Enstitüsü, Dergisi 23(2): 36-45.

[5] Assirey, E., Al-Qodah, Z., Al-Ahmadi, M. (2015): Impact of traffic density on roadside pollution by some heavy metal ions in Madinah city, Kingdom of Saudi Arabia. - Asian Journal of Chemistry 27(10): 3770-3776.

[6] Bat, L., Gündoğdu, A., Öztürk, M. (1999): Heavy Metals. - SDU Eğirdir Su Ürünleri Fak. Derg. 1998-1999, pp. 166-175

[7] Begum, H. A., Hamayun, M., Zaman, K., Shinwari, Z. K., Hussain, A. N. W. A. R. (2017): Heavy metal analysis in frequently consumable medicinal plants of Khyber Paktunkhwa, Pakistan. - Pak. J. Bot 49(3): 1155-1160.

[8] Boğa, A. (2007): Ağır Metallerin Özellikleri ve Etki Yolları - Çukurova Üniversitesi Tıp Fakültesi, Fizyoloji Anabilim Dalı, Adana 16: 218.

[9] Celik, A., Kartal, A. A., Kaska, Y. (2005): Determining the heavy metal pollution in Denizli (Turkey) by using Ro-binia pseudo-acacia L. - Environment International 31: 105-112. 
[10] Cetin, M., Sevik, H. (2016a): Measuring the impact of selected plants on indoor CO2 concentrations. - Polish Journal of Environmental Studies 25(3): 973-979.

[11] Cetin, M., Sevik, H. (2016b): Change of air quality in Kastamonu City in terms of particulate matter and $\mathrm{CO}_{2}$ amount. - Oxidation Communications 39(4-II): 3394-3401.

[12] Cetin M, Sevik H, Isinkaralar, K. (2017a): Changes in the particulate matter and $\mathrm{CO}_{2}$ concentrations based on the time and weather conditions: the case of Kastamonu. Oxidation Communications 40(1-II): 477-485.

[13] Cetin, M., Sevik, H., Saat, A. (2017b): Indoor air quality: the samples of Safranbolu Bulak Mencilis cave. - Fresenius Environmental Bulletin 26(10): 5965-5970.

[14] Cetin, M., Onac, A. K., Sevik, H., Canturk, U., Akpinar, H. (2018a): Chronicles and geoheritage of the ancient Roman city of Pompeiopolis: a landscape plan. - Arabian Journal of Geosciences 11: 798. DOI: 10.1007/s12517-018-4170-6.

[15] Cetin, M., Kalayci Onac, A., Sevik, H., Sen, B. (2018b): Temporal and regional change of some air pollution parameters in Bursa. - Air Quality, Atmosphere \& Health. DOI: https://doi.org/10.1007/s11869-018-00657-6.

[16] Cetin, M., Sevik, H., Yigit, N. (2018c): Climate type-related changes in the leaf micromorphological characters of certain landscape plants. - Environmental Monitoring and Assessment 190: 404. https://doi.org/10.1007/s10661-018-6783-3.

[17] Cetin, M., Sevik, H., Yigit, N., Ozel, H. B., Aricak, B., Varol, T. (2018d): The variable of leaf micromorphogical characters on grown in distinct climate conditions in some landscape plants. - Fresenius Environmental Bulletin 27(5): 3206-3211.

[18] Demirayak, A., Kutbay, H. G., Kilic, D., Bilgin, A., Huseyinova, R. (2011): Heavy metal accumulation in some natural and exotic plants in Samsun City. - Ekoloji 20(79): 1-11.

[19] Erdem, T. (2018): the change of heavy metal concentrations in some plants due to species, organelles and traffic densities. - Master Thesis, Kastamonu University Institute of Science Department of Forest Engineering, Kastamonu, Turkey.

[20] França, F. C., Albuuerque, A. M., Almeida, A. C., Silveira, P. B., Crescêncio Filho, A., Hazin, C. A., Honorato, E. V. (2017): Heavy metals deposited in the culture of lettuce (Lactuca sativa L.) by the influence of vehicular traffic in Pernambuco, Brazil. - Food Chemistry 215: 171-176.

[21] Galal, T. M., Shehata, H. S. (2015): Bioaccumulation and translocation of heavy metals by Plantago major L. grown in contaminated soils under the effect of traffic pollution. Ecological Indicators 48: 244-251.

[22] Gratani, L., Crescente, M. F., Varone, L. (2008): Long-term monitoring of metal pollution by urban trees. - Atmospheric Environment 42: 8273-8277.

[23] Gülgün, B., Güney, M., A., Aktaş, E., Yazici, K. (2014): Role of Landscape Architect in Interdisciplinary Planing of Sustainable Cities. - Journal of Environmental Protection and Ecology 15(4): 1877-1880.

[24] Gülgün, B., Yazici, K., Dursun, Ş., Balık, G. (2015): Forest plantation and alternative utilization of some cultivated plants in Turkey. $-15^{\text {th }}$ Scientific Geoconference, Albena/Bulgaria. SGEM 1: 377-383. DOI: 10.5593/SGEM2015/B51/S20.049.

[25] Kaya, L. G., Kaynakci-Elinc, Z., Yucedag, C., Cetin, M. (2018): Environmental outdoor plant preferences: a practical approach for choosing outdoor plants in urban or suburban residential areas in Antalya, Turkey. - Fresenius Environmental Bulletin 27(12): 79457952.

[26] Lei, J., Hasi, E., Sun, Y. (2015): Assessing the Influence of Different Road Traffic on Heavy Metal Accumulation in Rural Roadside Surface Soils of the Eastern Ordos Plateau Grassland in China. - In: Scholz, M. (ed.) Water Resources and Environment. CRC Press, Boca Raton, FL, pp. 247-252.

[27] Li, F. R., Kang, L. F., Gao, X. Q., Hua, W., Yang, F. W., Hei, W. L. (2007): Trafficrelated heavy metal accumulation in soils and plants in Northwest China. - Soil \& Sediment Contamination 16(5): 473-484. 
[28] Mossi, M. M. M. (2018): Determination of heavy metal accumulation in some shrub formed landscape plants. - Ph.D. Thesis, Kastamonu University, Institute of Science Department of Forest Engineering, Kastamonu, Turkey.

[29] Mutlu, E. (2016): The effects of lead-induced toxicity on metabolic biomarkers in common carp (Cyprinus carpio L.). - Fresenius Environ Bull 25(5): 1419-1427.

[30] Mutlu, E., Demir, T., Yanık, T., Anca Sutan, N. (2016): Determination of environmentally relevant water quality parameters in Serefiye Dam-Turkey. - Fresenius Environ Bull 25(12): 5812-5818.

[31] Okcu, M., Tozlu, E., Kumlay, A. M., Pehluvan, M. (2009): Ağır Metallerin Bitkiler Üzerine Etkileri. - Alınteri Dergisi 17: 14-26.

[32] Özel, S. (2019): The variation of heavy metal accumulation in some fruit tree organelles due to traffic density. - Master Thesis, Kastamonu University, Graduate School of Natural and Applied Sciences Department of Sustainable Agriculture and Natural Plant Resources, Kastamonu, Turkey.

[33] Ozel, H. B., Ozel, H. U., Varol, T. (2015): Using leaves of oriental plane (Platanus orientalis L.) to determine the effects of heavy metal pollution caused by vehicles. - Pol. J. Environ. Stud. 24(6): 2569.

[34] Ozturk, S., Bozdogan, E. (2015): The contribution of urban road trees on improving the air quality in an urban area. - Fresenius Environmental Bulletin 24(5): 1-9.

[35] Qing, X., Yutong, Z., Shenggao, L. (2015): Assessment of heavy metal pollution and human health risk in urban soils of steel industrial city (Anshan), Liaoning, Northeast China. - Ecotoxicology and Environmental Safety 120: 377-385.

[36] Pinar, B. (2019): The variation of heavy metal accumulation in some landscape plants due to traffic density. - Master Thesis, Kastamonu University, Graduate School of Natural and Applied Sciences Department of Sustainable Agriculture and Natural Plant Resources, Kastamonu, Turkey.

[37] Sawidis, T., Breuste, J., Mitrovic, M., Pavlovic, P., Tsigaridas, K. (2011): Trees as bioindicator of heavy metal pollution in three European cities. - Environmental Pollution 159: 3560-3570.

[38] Saleh, E. A. A. (2018): Determination of heavy metal accumulation in some landscape plants. - Ph.D. Thesis, Kastamonu University Institute of Science Department of Forest Engineering, Kastamonu, Turkey.

[39] Sevik, H., Ozel, H. B., Cetin, M., Özel, H. U., Erdem, T. (2018): Determination of changes in heavy metal accumulation depending on plant species, plant organism, and traffic density in some landscape plants. - Air Quality, Atmosphere \& Health. https://doi.org/10.1007/s11869-018-0641-x.

[40] Suzuki, K., Yabuki, T., Ono, Y. (2009): Roadside Rhododendron pulchrum leaves as bioindicators of heavy metal pollution in traffic areas of Okayama. - Japan, Environ Monit Assess 149: 133-141.

[41] Tam, N. F. Y., Liu, W. K., Wang,. M. H., Wong, Y. S. (1987): Heavy metal pollution in roadside, urban parks and gardens in Hong Kong. - Sci. Toplam Environ. 59: 325-328.

[42] Tanushree, B., Chakraborty, S,. Bhumik, F., Piyal, B. (2011): Heavy metal concentrations in street and leaf deposited dust in Anand City, India. - Research Journal of Chemical Sciences 1(5): 61-66.

[43] Turkyilmaz, A., Sevik, H., Isinkaralar K, Cetin M (2018a) Use of tree rings as a bioindicator to observe atmospheric heavy metal deposition. - Environmental Science and Pollution Research. DOI: 10.1007/s11356-018-3962-2.

[44] Turkyilmaz, A., Sevik, H., Cetin, M. (2018b): The use of perennial needles as biomonitors for recently accumulated heavy metals. - Landsc Ecol Eng 14(1): 115-120. https://doi.org/10.1007/s11355-017-0335-9.

[45] Turkyilmaz, A., Sevik, H., Cetin, M. Saleh, EAA. (2018c): Changing of heavy metal accumulation dependent on traffic density in some landscape plants. - Polish Journal of Environmental Studies 27(5): 2277-2284. 


$$
-6734 \text { - }
$$

[46] Turkyilmaz, A., Cetin, M., Sevik, H., Isinkaralar, K., Saleh, E. A. A. (2018d): Variation of heavy metal accumulation in certain landscaping plants due to traffic density. Environment, Development and Sustainability. DOI: https://doi.org/10.1007/s10668-0180296-7.

[47] Turkyilmaz, A., Sevik, H., Isinkaralar, K., Cetin, M. (2018e): Using Acer platanoides annual rings to monitor the amount of heavy metals accumulated in air. - Environ Monit Assess 190: 578. https://doi.org/ 10.1007/s10661-018-6956-0. 